\title{
Literatura przedmiotu z lat 1939-1949 na temat losów bibliotek w czasie okupacji niemieckiej
}

B adając historię bibliotek $\mathrm{w}$ czasie II wojny światowej na terenie II Rzeczpospolitej, musimy się odnieść nie tylko do źródeł, ale i wszelkiego rodzaju opracowań, literatury przedmiotu. Piśmiennictwo bibliologiczne, naukoznawcze, monografie historyczne zagadnien, instytucji i organizacji stanowią źródła wiadomości o bibliotekach stosunkowo najpełniejsze i najbardziej kompetentne, zwłaszcza przy odczuwalnym niedostatku bibliologicznych wydawnictw źródłowych. Przy czym należy pamiętać, że granica między opracowaniami a źródłami bywa tutaj płynna, np. w przypadku adnotowanych spisów bibliograficznych. Naturalnie, publikacje tego typu zawierają często jednostkowe informacje źródłowe, ale w nich właśnie można znaleźć najwięcej informacji merytorycznych, przede wszystkim w fachowych i naukowych opracowaniach bibliotekarzy i ich wspomnieniach. Jak stwierdza Barbara Bieńkowska „W opracowaniach dotyczących innych kwestii tematyka księgozbiorów zajmuje oczywiście dalsze miejsca, ale równie ż w znaczący sposób pomnaża o nich wiedzę" ${ }^{1}$, mając na myśli publikacje naukowe. Jednak historyk dziejów bibliotek czasów wojny i okupacji nie może pozostać obojętny wobec wszelkich przekazów na temat ich losów, przekazów o charakterze nienaukowym, dokumentalnym, literackim, czy nawet propagandowym, publikowanych w różnego rodzaju wydawnictwach.

Dlatego w badlaniach nad dziejami bibliotek w czasie wojny i okupacji tak istotne są wszelkie publikacje $z$ lat 1939-1945, a także późniejsze - $z$ lat 1946-1947, gdyż niezależnie od wartości merytorycznej informacji, jakie zawierały, są $z$ jednej strony uczestnikiem a $z$ drugiej, świadectwem opisywanych wydarzeń.

Baza źródłowa do badań nad historią bibliotek w czasie II wojny światowej na terenie II Rzeczpospolitej jest ogromna i bardzo zróżnicowana. Zakres i zasięg tej problematyki najlepiej ukazuje jej bibliografia. Przylkładem takiego opracowania jest „Bibliografia” do publikacji „Straty bibliotek w czasie II Wojny Światowej w granicach Polski z 1945 roku. Wstępny raport o stanie wiedzy", autorstwa Urszuli Paszkiewicz ${ }^{2}$. Bibliografia, obejmująca piśmiennictwo dotyczące strat poniesionych przez biblioteki naukowe, publiczne, szkolne i fachowe oraz prywatne w granicach Polski z 1945 r., zawiera 908 pozycji wydanych clo 1993 r. Mimo, że jest to bibliografia niepełna, uwzględniająca tylko ważniejsze pozycje $z$ piśmiennictwa regionalnego, a pomijająca dużą część „wzmianek o stratach bibliotek, zawartych w monografiach miast, instytucji, stowarzyszeń, szkół i osób, które mogły poruszać problematykę strat wojennych" ${ }^{3}$, daje øbraz wagi baclań nad dziejami bibliotek dla prac z zakresu historii kultury, literatury, naukoznawstwa (straty w zbiorach bibliotecznych dotknęły wszystkie dyscypliny naukowe uprawiane w Polsce mięclzywojennej), historii politycznej, prawa, biografistyki, historii mniejszości narodowych, wyznań religijnych, oświaty 
i szkolnictwa. Szczególne znaczenie w tym kontekście mają baclania nad historią bibliotek w skali regionalnej, lokalnej. Przykładem może być tutaj bibliografia piśmiennictwa poświęconego okupacyjnym losom i stratom bibliotek krakowskich zestawiona przez Piotra Lechowskiego (171 opublikowanych opracowań) w monograhii „Biblioteki Krakowa w okresie okupacji niemieckiej 1939-1945"4.

Ów dorobek piśmienniczy powstawał w oparciu o źródlla, których waga była nierówna, przede wszystkim $z$ powodu strat $w$ dokumentacji bibliotecznej w czasie okupacji i różnej wartości ocalałej dokumentacji ${ }^{5}$. Straty kultury polskiej, w tym bibliotek, w latach 1939-1945 były tak ogromne, że informowanie o nich, ich dokumentowanie, w tym poprzez publikacje różnego rodzaju - w trakcie okupacji niemieckiej i zaraz po ustąpieniu wojsk niemieckich $z$ terenu Polski w $1944 \mathrm{r}$ - - stało się niejako obowiązkiem narodowym, zwłaszcza w kontekście ewentualnych rewindykacji i odszkodowań ${ }^{6}$. Przy czym problem rewindykacji i odszkodowań pojawiał się w opracowaniach także w następnych dziesięcioleciach? .

Wśród autorów informacji na temat okupacyjnych losów bibliotek w latach 1939-1949 przeważały osoby, które nie specjalizowały się w bibliotekarstwie. Stąd np. w zbiorach Państwowego Instytutu Książki już w 1949 r. znalazło się m.in. kilkanaście tysięcy wycinków prasowych dotyczących książki i biblioteki ${ }^{8}$. W niniejszym opracowaniu chciałbym się skupić przede wszystkim na publikacjach istotnych $z$ punktu widzenia baclacza historii bibliotek.

Pierwsze, ważniejsze publikacje, odnoszące się do strat bibliotek polskich, wyclano na emigracji. Powstały dzięki akcji rejestracji strat i szkód wojennych rozpoczętej w listopadzie 1939 r. przez warszawską komisję Antoniego Olszewskiego. Komisja ta po utworzeniu Delegatury Rząclu RP na Kraj została włączona do Departamentu Likwidlacji Skutków Wojny Delegatury Rządu na Kraj jako dział literatury i piśmiennictwa. Kierował nim Wacław Borowy. Owocem prac Departamentu było powstanie w 1942 r. książki „The Nazi-Kultur in Poland by several Authors of necessity temporarily ananymous (written in Warsaw under the German occupation)", w której rozdział VI poświęcony był losom bibliotek polskich podczas wojny i okupacji, wg stanu wiedzy na sierpień 1941 r., a jego autorem był prawdopodobnie Józef Grycz .

Informacje $z$ kraju - przesyłane przez Komisję A. Olszewskiego, a także inne instytucje Polskiego Państwa Podziemnego: Departament Oświaty i Kultury Delegatury Rząclu ze Stanisławem Lorentzem, który zajmował się sprawami kultury, Departament Informacji Delegatury Rządu, Wydział Informacji Biura Informacji i Propagandy Komendy Głównej $Z W^{10}$ - docierały do różnych agend emigracyjnego Rządu Polskiego. Już w 1940 r., na terenie Francji, powstał zespół, który działal później jako Biuro Rewindykacji Strat Kulturalnych przy (od 1940 r.) Ministerstwie Informacji i Dokumentacji. Ministerstwo - juz w Wielkiej Brytanii - opublikowało w $1941 \mathrm{r}$ : informacje na temat strat kultury polskiej w "The German occupation in Poland" "1. Biuro Rewindykacji Strat Kulturalnych działało później przy Biurze Prac Politycznych, Ekonomicznych i Prawnych, a od lipca 1942 r. w ramach Ministerstwa Prac Kongresowych. Jego zadaniem było przygotowanie roszczeń wobec Niemców i ich koalicjantów. Zbierając informacje o stratach kultury polskiej, dzięki działalności Departa- 
mentu Likwidlacji Skutków Wojny, Biuro opracowało publikację „Cultural los ses of Poland. Index of Polish cultural losses during the German occupation 1939-1944”12 - „Straty kultury polskiej”. „Katalog strat kultury polskiej pod okupacją niemiecką 1939-1944”, oraz „Straty kultury polskiej 1939-1944”" . Ciekawe, że Biuro Rewindykacji Strat Kulturalnych zdobywało informacje nie tylko z kraju - akty represji wobec książki i bibliotek odnotowywała również prasa podziemna ${ }^{14}$, ale analizowało także prasę niemiecką i współpracowało $z$ siecią korespondentów/agentów w Szwajcarii, Szwecji, Portugalii, Hiszpanii, Stanach Zjednoczonych oraz w samych Niemczech ${ }^{15}$. Oczywiście dane te miały charakter fragmentaryczny, niepełny - ostatnie meldunki z Kraju pochodziły $z$ lutego 1943 r. - często sprzeczny z rzeczywistością, co w naturalny sposób wynikało $z$ uwarunkowań $w$ jakich pracowali informatorzy Biura. Jednak warto podkreślić, że kwestia strat bibliotecznych była obecna zarówno w piśmiennictwie naukowym $^{16}$ jak i w prasie emigracyjnej, zarówno w czasie wojny ${ }^{17}$, jak i po niej ${ }^{18}$. Przy czym wartość opracowań emigracyjnych wynikała przede wszystkim ze szczególnej uwagi, jaką poświęcały losom kultury polskiej, w tym bibliotek, na Ziemiach Wschodnich II Rzeczpospolitej ${ }^{19}$.

Również działalność okupantów pozostawiła po sobie ślady, nie tylko w postaci zarząclzeń wykonawczych, raportów i korespondencji pomiędzy poszczególnymi agendami władz okupacyjnych, ale i publikacji prasowych, w tym kierownika Głównego Zarząlu Bibliotek (Hauptverwaltung der Bibliotheken im GG) Gustava Abba ${ }^{20}$. W tym kontekście warto wymienić wybór dokumentów źrócllowych pt. „Biblioteki naukowe w Generalnym Gubernatorstwie w latach 19391945" w opracowaniu Andrzeja Mężyńskiego ${ }^{21}$, a także zwrócić uwagę na niemieckojęzyczne powojenne wydawnictwa źródłowe i opracowania ${ }^{22}$. Znamienna jest przy tym stosunkowo nieznaczna ilość oryginalnych, niemieckich opracowań na temat polityki kulturalnej władz okupacyjnych w Polsce, co świadczy o stanie świadomości niemieckiej w tym zakresie.

W latach czterdziestych XX w. rejestrację strat bibliotecznych kontynuował Kościól katolicki, co przyniosło publikację szeregu wartościowych opracowań ${ }^{23}$. Fragmentarycznymi danymi na temat losów swoich bibliotek dysponowały także inne Kościoly i związki wyznaniowe (przede wszystkim społeczność żydowska ${ }^{24}$ ). Ponadto ewidencję strat, ich dokumentację i publikację informacji o stanie swoich zbiorów, prowadziły we własnym zakresie organizacje spoleczne, oświatowe ${ }^{25}$, kulturalne ${ }^{26}$ i naukowe $e^{27}$.

Ogólnokrajowa rejestracja szkód wojennych rozpoczęta została w październiku 1944 r. na podstawie dekretu PKWN z 27 września tegoż roku. Prowadziło ją Biuro Odszkodowań Wojennych (BOW) funkcjonujące przy Prezydium Rady Ministrów we współpracy z Resortem Administracji Publicznej. Powołano odpowiednie komórki w urzędach wojewódlzkich, miejskich, gminnych i starostwach, które mialy dokumentować straty wojenne na terenie Polski Centralnej, poniesione w okresie od 1.09.1939 do $9.05 .1945 \mathrm{r}^{28}$. W ankietach BOW znalazły się rubryki dotyczące strat ksiązek, jednak informacje tego typu traktowane były marginalnie i wybiórczo. Pytanie o biblioteki znalazło się w ankietach na temat strat administracji publicznej, związków religijnych i stowarzyszeń społecznych oraz w kwestionariuszach przeznaczonych clla osób prywatnych ${ }^{29}$. Od 1945 r. rejestrację strat kulturalnych $-z$ wyłączeniem bibliotek - przejął Wy- 
dział Rewindykacji i Odszkodowań ${ }^{30}$ Ministerstwa Kultury i Sztuki. Rejestrację strat bibliotecznych prowadził - od 21.9.1944 do 1.1.1947 $\mathrm{r}^{31}$ - Wydział Bibliotek $^{32}$ Ministerstwa Oświaty pod kierownictwem Józefa Grycza ${ }^{33}$. Jak podkreśla B. Bieńkowska „Tak szeroko zakrojone w skali krajowej przedsięwzięcie miało na celu przede wszystkim zgromadzenie dokumentacji do roszczeń odszkodowawczych zgłaszanych przez władze polskie na forum międzynarodowym w latach 1945-1947. Całą akcję cechowały: pośpiech, rozproszenie wysiłków, brak koordynacji i dopracowania metod a w efekcie fragmentaryczność i nieprzystawalność wyników. Główny nacisk spoczywał na oszacowaniach ilościowych i wycenach finansowych a do nich właśnie ankiety dawały najmniej pewną podstawę (...) w kwestionariuszu rozeslanym przez Min. Ośw. znajdowało się czternaście rubryk: liczba porządlkowa; miejscowość; nazwa biblioteki; właściciel biblioteki; wartość; rodzaj biblioteki; liczba tomów w sierpniu 1939 - książek, czasopism; straty zbiorów spowodowane przez Niemców, luclność; straty inwentarzy i katalogów; sposób zniszczenia książek; udokumentowanie, świadkowie; obecny stan; data zgłoszenia strat i szkód; nazwisko i adres zgłaszającego. W najsolidniej nawet wypełnionych kwestionariuszach wiele rubryk pozostawało pustych $z$ braku wiadomości, wiele danych wpisywano szacunkowo. Niemniej te arkusze zbiorcze pozwalały na zorientowanie się $\mathrm{w}$ sytuacji bibliotek w terenie. Znacznie więcej realiów zawierały ankiety rejestrujące stan poszczególnych placówek, które stanowiły podstawy do zestawień ogólnych (...) Oprócz wspomnianych wyżej mankamentów bilans strat dokonany w $1947 \mathrm{r}$. miał te generalne ograniczenia, że $z$ założenia obejmował tylko biblioteki szkolne, powszechne oraz naukowe wyłącznie $z$ terenów Polski centralnej (bez Ziem Odzyskanych i terytoriów utraconych na wschodzie). Nie uwzględniono księgozbiorów innych typów i form własności oprócz państwowej, samorządowej i - rzadko - społecznej. Pominięto zbory prywatne. W jednym $z$ zestawień $z$ dn. 1 sierpnia 1945 r. znalazła się jednorazowa wzmianka o stratach dwóch milionów tomów prywatnych, w tym przypadku nie poparta dokumentacją. Była to liczba szacunkowa, nie wykorzystano bowiem danych $z$ ankiet indywiclualnych zgromadzonych wówczas innymi kanałami administracyjnymi. Właśnie dane zbiorcze przygotowane w Min. Ośw. przez dlugie lata przyjmowano w piśmiennictwie fachowym jako pełne (niekiedy $z$ drobnymi modyfikacjami), zapominając $z$ czasem o ich zminimalizowanym zakresie (...) J. Grycz i jego współpracownicy zawsze bardzo mocno podkreślali, że są to obliczenia niekompletne, prowizoryczne, przyblizone - i tak było w istocie" ${ }^{34}$.

Mimo tej sytuacji w latach 1945-1947 ukazało się szereg wartościowych, pod względem źródłowym, publikacji na temat losów bibliotek w czasie i zaraz po okupacji niemieckiej. Do najważniejszych wśród nich należały artykuly J. Grycza i K. Janiczka, oparte na pracach rejestracyjnych w Ministerstwie Oświaty ${ }^{35}$ Dużo istotnych informacji przynosiły opracowania o charakterze regionalnym ${ }^{36}$ i krajowym ${ }^{37}$, w tym poświęcone określonym typom bibliotek ${ }^{38}$ i zbiorów ${ }^{39}$, chociaż nie były wolne od błęclów, ze względu na fragmentaryczność, niepełność danych. $Z$ opracowań regionalnych, najwięcej wartościowych publikacji poświęconych było Wielkopolsce. Można tutaj wymienić publikacje poświęcone sytuacji bibliotek $\mathrm{w}$ regionie ${ }^{40}$ i poszczególnych miastach, głównie w Poznaniu ${ }^{41}$ i Kórniku ${ }^{42}$. Cenne publikacje dotyczyły bibliotek - głównie naukowych - funk- 
cjonujących w największych miastach centralnej Polski. Wiele opracowań odnosilo się do bibliotek warszawskich ${ }^{43}$, a także m.in. krakowskich ${ }^{44}$, lubelskich $^{45}$, lódzkich ${ }^{46}$, toruńskich ${ }^{47}$.

Publikowano także opracowania poświęcone ważniejszym bibliotekom naukowym w mniejszych ośrodkach ${ }^{48}$, takim jak np. Biblioteka im. Zielińskich przy Towarzystwie Naukowym Płockim ${ }^{49}$, bibliotekom publicznym i szkolnym ${ }^{50}$, istotnym dla społeczności lokalnych ${ }^{51}$, a także zbiorom zrabowanym w czasie wojny i odnalezionym w następnych latach ${ }^{52}$. W 1946 r. pojawiła się inicjatywa Naczelnej Dyrekcji Bibliotek wydania „Księgi wspomnień” bibliotekarzy, aktywnych w czasie okupacji. Część $z$ nich ukazała się dopiero w publikacji „Walka o dobra kultury" z $1970 \mathrm{r}^{53}$.

Pierwszy okres edycji materiałów poświęconych stratom wojennym bibliotek zamyka niejako „Sprawozdanie w przedmiocie strat i szkód wojennych w Polsce w latach 1939-1945" ${ }^{\prime 4}$, gdyż akcja dokumentacyjna została (w 1947 r.) przerwana przez władze, a zebrane materiały szyblko traciły na aktualności względnie ulegały rozproszeniu ${ }^{55}$. Jednak w latach 1948-1949 ukazało się szereg istotnych publikacji będących jej pokłosiem, a przede wszystkim efektem indywidualnych prac historyków, bibliotekarzy i archiwistów, w tym m.in.: opracowanie Edwarda Chwalewika poświęcone exlibrisom ${ }^{56}$, artykuł Adolfa Chybińskiego na temat polskich zbiorów muzycznych ${ }^{57}$, opracowanie L. Zembrzuskiego o dziejach bibliotek lekarskich ${ }^{58}$, publikacje o zbiorach odzyskanych ${ }^{59}$, kolejne publikacje na temat strat dóbr kultury w poszczególnych miejscowościach, głównie w Warszawie ${ }^{60}$ a takze m.in. w Poznaniu ${ }^{61}$. Wartość tych opracowań podnosi fakt, że w odróżnieniu od okresu poprzedniego, ich autorami byli przede wszystkim specjaliści, dysponujący wiedzą na temat zbiorów i organizacji bibliotek.

Ogólna ocena dorobku piśnienniczego lat 1939-1949 może być tylko pozytywna. W ekstremalnych warunkach, związanych $z$ okresem okupacji niemieckiej, wejściem wojsk sowieckich do Polski, instalacją tzw. Rządu Lubelskiego, środowisku bibliotekarskiemu, a szerzej mówiąc naukowemu, udało się udokumentować i opisać okupacyjne dzieje bibliotek polskich na podstawie tych źródel do których miało dostęp i które mogło wykorzystać. I mimo to, że opracowania $z$ lat 1939-1949 z przyczyn wyżej omówionych, nie oddawały w pełni rzeczywistości w zakresie losów bibliotek polskich w okresie okupacji niemieckiej, to przez dziesięciolecia informacje w nich zawarte, były cytowane w literaturze przedmiotu.

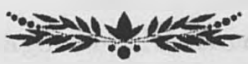

\section{Przypisy:}

${ }^{1}$ B. Bieńkowska, Biblioteki na wschodnich zienniach II Rzeczypospolitej. Infor:17ator, (red.), B. Bieńkowska, Poznań 1998, s. 9-10.

${ }^{2}$ A. Mężyński, (red.), Warszawa 1994.

${ }^{3}$ Ibidem, s. 6.

${ }^{4}$ Kraków 1999, s. 131-138. 
${ }^{5}$ Zob. m.in., prace M. Lecha, Materialy do dziejów ksiązki i czytelnictwa polskiego $w$ bibliotekach $i$ archiwach leningradzkich, „Biuletyn Informacyjny Biblioteki Narodowej 1968", nr 3, s. 25-27; tenże: Akta notarialne jako źródła do badań nad ksjęgozbiorami domowynu, w: Studia o Książce, t. 9, 1979, s. 187-201; tenże: Kartoteka żródel archiwalnych do dziejów ksiązki i czytelnictwa polskiego, 1800-1939, „Biuletyn Informacyjny Biblioteki Narodowej 1964", z. 4, s. 14-15; K. Głombiowski, O tunkcjonalną koncepcje nauki o ksiązce, Wroclaw 1970; K. Migon', Uwagi o rozwoju i perspektywach historiografii ksiązki, w: Studia o Ksiazze, t. 5, 1975, s. 15-44; tenże: Metodologia bibliotekoznawstwa i nauki o informacji naukowej, Poznań 1976; S. Siekierski, Panniętniki jako źródlo badań czytelnictwa, w: Studia o Ksiąze, t. 6, 1976, s. 3-22; H. Chamerska, Akta hipoteczne i notarialne jako źródla do badań nad ksieggozbiorami prywatnymi XIXXX w., w: Z Badań nad Polskimi Ksieggozbiorami Historycznymi, z. 3, 1977, s. 5-22; Z. Gaca-Dąbrowska, Sytuacja w badaniach nad dziejami bibliotek i bibliotekarstwa w XLX i XX w., w: Studia o Ksiąze, t. 12, 1982, s. 71-84; A. Żbikowska-Migon, Wydawnictwa zródlowe do dziejów ksiąziki w Polsce stan i potrzeby, tamże, s. 32-47; M. Dębowska, Bibliologia, bibliografia, bibliotekoznawstwo...; Straty bibliotek w czasie II wojny światowej w granicach Polski z 1945 roku. Wstępny raport o stanie wiedzy. (Red.), A. Mężyński, Warszawa 1994; Prace B. Bieńkowskiej: Kilka uwag i propozycji w sprawie badań księgozbiorów historyczuych, w: Studia o Ksiązce, t. 16, 1986, s. 3-15; taż: Wokół raportu o stratach bibliotek polskich w czasie II wojny swiatowej. Problematyka bibliologiczna, w: Symposia bibliologica. Warszawa 1995, s. 86-92; taż: Zastosowania bibliologii w pracach Biura Pełnomocnika Rządu do Spraw Dziedzictwa Kulturalnego za granica, (na przykładzie urzędowej dokumentacji strat bibliotek w Polsce podczas II wojny światowej). „Roczniki Biblioteczne”, t. 45, 2001, s. 3-27; J. Plis, Źródta dotyczące strat bibliotek w czasie II wojny światowej. Ocena ich wiarygodności, w: Symposia bibliologica, Warszawa 1995, s. 139-149; H. Łaskarzewska, Dzialalność Pracowni Dokumentacji Ksjęgozbiorów Historycznych Biblioteki Narodowej. Wspólpraca krajowa i miedzynarodowa; taz: Zalozienia wstępne dotyczące „Informatora o polskich ksiegozbiorach historycznych i powstalych na ziemiach polskich po 1950 r., w: ibidem, s. 7-22; S. Waligórski, Wokól raportu o stratach bibliotek w czasie II woiny światowej-problemy informatyczne, w: ibidem, s. 125-130; Z. Gaca-Dąbrowska, Historyk bibliotelk polskich wobec Raportu, w: ibidem, s. 131-138; J. Puchalski, Badania nad źródłami do dziejów bibliotek w granicach II Rzeczypospolitej w latach 1939-1945: zarys problematyki, w: E scientia et amicitia. Studia poświęcone profesorowi Edwardowi Potkowskiemu, Warszawa-Pułtusk 1999, s. 151-157; J. Szymański, Trudności z identyfikacją bibliotek na zienniach polskich w I polowie XX wieku, „Roczniki Biblioteczne”, t. 45, 2001, s. 41-54; U. Paszkiewicz, Wybrane problemy dokumentacji zbiorów bibliotecznych na wschodnich ziemiach Rzeczypospolitej do 1.939 roku, ibidem, s. 55-90.

${ }^{6}$ W serii: Prace i materialy Wydziału Rewindykacji i Odszkodowań Ministerstwa Kultury i Sztuki, w latach 1945-1951, ukazało się 14 publikacji. W 1945 r. wydano pracę W. Suchodolskiego: Zagadnienia prymatu strat kulturalnych w ogólnym programie odszkodowan (Rebuilding culture. The meaning of the reparation for Poland, Warsaw 1945). Inne opracowania $z$ omawianej serii to: W. Borowy, Tezy ogólne w sprawie rewindykacji i odszkodowań z zakresu kultury i sztuki, Warszawa 1945.

Problem rewindykacji podnoszony był także w prasie codziennej, np. W. Kłyszewski, Rewindykacja, w: Odrodzenie 1945, nr 23; A. K, Jeszcze o rewindykacji mienia narodowego z Niemiec do Polski, „Rzeczpospolita”, nr 11, 1947; Jotka, Zagadnienia rewindyka- 
cyjine (stanowisko MKiS), "Kurier Codzienny”, nr 55, 1947; w wydawnictwach okolicznościowych np. Warsaw Accuses. Exhibition catalogue, Warsaw 1945; w czasopiśniennictwie naukowym, np. W. Antoniewicz, Rewindykacje $i$ odszkodowania zabytków archeologicznych zien Polski, w: Z Otchlani Wieków, z. 7-10, 1946, s. 56-57; W. Kieszkowski, Składnica muzealna Paulinum i rewindykacja zabytków na Dolnym Śląsku, w: Panniętnik Związku Historyków Sztuki i Kultury, t. 1, 1948. Należy jednak zwrócić uwagę, że wymienione publikacje w większyn stopniu dotyczyły problematyki kultury artystycznej, niz bibliotek. Tym ostatnim więcej uwagi poświęcił m.in. F. Szymiczek w artykule: Akcja zabezpieczająca i rewindykacyjna na Śląsku, "Przegląd Zachodni", n1 2, 1946, s. 192-195; [S. M. Sawicka] St. M. S., Rewindykacja mienia kulturalnego aliantów odnalezionego w Nienczech, w: Biuletyn Historii Sztuki i Kultury, ur 1, 1946 , s. 133.

${ }^{7}$ L. Gondek, Polskie misje wojskowe 1935-1949. Polityczno-pramne, ekonomiczne i wojskowy problemy likwidacji skutków wojny na obszarze okupowanych Niemiec, Warszawa 1981; Tenze: Probleny restytucyjne w pracach Polskiej Misji Wojskowej w Niemczech. „Przegląd Zachodni”, nr 3, 1979; W. Kowalski, Likwidacja skutków II wojny światowej $w$ dziedzinie kultury, Warszawa 1994; J. Plis, Ksiegozbiory rozproszone. Problemy prawne i biblioteczne, „Archiwa, Biblioteki i Muzea Kościelne”, 1996, s. $405-445$.

${ }^{8}$ M. Dęlıowska, Bibliologia, bibliografia, bibliotekoznawstwo, informacja naukowa. Wybór prac, Warszawa 1999, s. 12-14.

${ }^{9}$ [Red.] W. Borowy, Straty bibliotek $w$ czasie II wojny światowej..., s. 18.

${ }^{10}$ Straty bibliotek w czasie II wojny światowej..., s. 15.

${ }^{11}$ London, (po czerwcu 1941 r.), s. 431-500. Wersja pelna, pod tytułem The German new order in Poland miala 2 wydania w 1942 r. i jedno w 1943.

12 London 1944, (ed.) by Charles Estreicher, London 1945.

${ }^{13}$ Praca zbiorowa pod red. A. Ordeggi (J. Hulewicza) i T. Terleckiego, t. 1-2, Glasgow 1945. Inne publikacje to m.in.: German destruction of cultural life in Poland. Documents relating to the administration of occupied countries in Eastern Europe, nr 2, New York [br. d.]; G. Godden, Murder of a nation. German destruction of Polish culture, London 1943.

${ }^{14} \mathrm{~Np}$. Biblioteki $\mathrm{i}$ ksiegarnie pod okupacją, w: Kultura Jutra, nr 1, 1943, s. 21-23.

${ }^{15}$ W. Kowalski, Likwidacja skutków II wojny światowej..., s. 17-20.

${ }^{16}$ M. Danilewiczowa, Losy bibliotek polskich, Londyn 1942.

17 Taż: Biblioteki polskie pod okupacją niemiecką, „Wiadomości Polskie”, nr 12, Londyn 1943 , s. 1.

${ }^{18}$ Taż: Straty wojenne bibliotek polskich, w:Teki Historyczne, nr 1, Londyn 1948, s. $1-26$.

${ }^{19}$ Analogicznie do terenów okupowanych przez Niemcy, talkże i w przypadku okupacji sowieckiej starano się dokumentować stan i straty kultury polskiej, czego wyrazem byla m.in. publikacja: F. E., The Soviet Occupation of Poland 1939-1941, Londyn 1945.

${ }^{20}$ Polen. Generalgouvernement. Zentralblatt fuer Bibliothekswesen, 1941, s. $162-$ 163; Tenze: Bibliotheken des Generalgouvernement im Kriegseinsatz, Krak. Zeit., 1943, nr 99, s. 5 i inne. Zob. także m.in. S. Frauendorfer, Das landwirtschaftlichen Bibliothekswesen im Generalgouvernement. Berichte der Landwirtschaftlichen Forschungsanstalt des Generalgouvernements 1944, t. 2, s. 1-14; A. Lattermann, Geschichte und Aut- 
gaben der Staats und Universitätsbibliothek Posen, Zentralblatt für Bibliothekswesen, t. 1, 1941, s. 11-18; H. von Pozniak, O. Sclineider, Wiener Zeitungswissenschaftler in Generalgouvernement, Zeitungswissenschaft, t. 10, 1942, s. 549-559; O. Walde: Nene Bïcher- und Bibliotheksgeschichtliche Forschungen in deutschen Bibliotheken, Nordisk Tidskrift för Bokoch Bibliotheksväsen, 1942, s. 225-230. Więcej zob. w: J. Kowalik: Polonica niemieckie za czas od 1. września 1939 do 31 grudnia 1948 roku, Paryż 1952.

${ }^{21}$ Przy wspólpracy H. Łaskarzewskiej, Warszawa 2003. Obok dokumentów okupacyjnych władz niemieckich publikacja ta zawiera we wstepie omówienie struktury władz administracyjnych GG, w tym Glównego Zarządu Bilıliotek (Hauptverwaltung der Bibliotheken im GG) oraz archiwów, w których można znaleźć dokumenty władz niemieckich odnoszące się do bibliotek polskich. Opracowanie to ma kapitalne znaczenie dla badań źródłowych nad dziejami naukowych bibliotek polskich na terenie GG.

${ }^{22}$ Obok omawianych przez A. Mężyńskiego publikacji: M. Komorowski, Die wissenschaftlichen Bibliotheken im Generalgouvernement Polen (1940-1945). In: Bibliothek, Forschung und Praxis, nr. 1, 1983, s. 69-75; J. Pirożński, K. Ruszajowa, Die nationalsozialistische Bibliothekspolitik in Polen während des Zweiten Weltkrieges, w: Bibliotheken wärhend des Nationalsozialismus, t. 1, Wiesbaden 1989, s. 199-225; A. Rapmund, Die deutsche Bibliothekspolitik in der Tschechoslowakei und in Polen wahrend des 2. Weltkrieges, Berlin 1993 (rozprawa doktorska), warto zwrócić uwage także na opracowania: H. Heller, Probleme der polnischen Kultur, Berlin 1948; Die Musikbestände der Warschauer Bibliotheken in der Nachkriegszeit. Kulturprobleme des neuen Polen, 1952, nr 9, s. 9-11; Staatsbibliothek zu Berlin, Preußischer Kulturbesitz. Die Beziehungen der Berliner Staatsbibliotheken nach Polen. Reflexionen zur Zeit- und Bestandsgeschichte, Wiesbaden, 1997; Aus der Staatsbibliothek zu Berlin. Preußischer Kulturbesitz, Bd. 5; Deutsche Politik in Polen 1939-1945. Aus dem Diensttagebuch von Hans Frank, Generalgouverneur in Polen. Innanuel Geiss; Wolfgang Jacobmeyer ( $\mathrm{Mg}$.). Opladen 1980; A. Mężyński: Die Verluste der polnischen Bibliotheken wälurend des Zweiten Weltkrieges inn Lichte neuer Archivtorschungen, w: Displaced books - Bucherrueckgabe aus zweirlei Sicht. 2. durchges. und erw. Aut7. „Laurentius Sonderheft”, Hannover 1999, s. 34-40.

${ }^{23}$ M.in. S. Styś, Biblioteka teologiczna kolegium OO. Jezuitów „Bobolanum”” „Bibliotekarz", nr 8/9, 1946, s. 186-187; [S. Wyszyński] X. S. w: Z Biblioteki inn. XX Chodyńskich przy Seminarium Wloclawskim. Kronika Diecezji Whocławskiej, 1945, nr 2, s. 100101; J. Zawadzki: Sprawozdanie ze stanu bibliotek i archiwów diecezji warmińskiej. Zapiski Towarzystwa Naukowego w Toruniu, t. 13, z. 1/4, 1947, s. 103; A. Liedtke, Biblioteka Seminarium Duchownego w Pelplinie. Zapiski Towarzystwa Naukowego w Toruniu, t. 13, z. 1/4, 1947, s. 89-92; S. Chodyński, Biblioteka Kapituly Włoclawskiej, Uzup. rozdzialem o katalogach autorstwa S. Librowskiego, Wlocławek 1949.

${ }^{24}$ Tentative list of Jewish cultural treasures in axisoccupied countries. By the research staff of the Commission on European Jewish Cultural Reconstruction, New York 1946.

${ }^{25}$ M.in., Towarzystwo Czytelni Ludowych, zob. artykuly: TCL w Ostrowie wznawia swoją działalnośc, „Głos Ostrowski”, nr 9, 1945, s. 3; Z. Wyrębski, TCL na Śląsku, „Bibliotekarz", nr 5, 1946, s. 118.

${ }^{26}$ A. Chybiński, Wojenne losy polskich zabytków muzycznych, „Ruch Muzyczny”, nr 1,1945 , s. 9-11. 
${ }^{27}$ Dzialalność gabinetów i zakladów badawczych w okresie 1937-1939 i ich losy wojenne, „Rocznik Towarzystwa Naukowego Warszawskiego”, 1938-1945, s. 26-41.

${ }^{28} \mathrm{~J}$. Plis, Zródla..., s. 140.

${ }^{29}$ AAN. Min Adm. Publ., sygn. 856, s. 31-58, 77-80.

${ }^{30}$ Później dzialal pod nazwą Biura Rewindykacji i Odszkodowań.

${ }^{31}$ Pojedyncze ankiety napływały jeszcze w 1948 r., ale nie były juz przedmiotem zbiorczych analiz. Zob. B. Bieńkowska: Potyczki ze źródłami bibliologicznymi..., przypis nir 3 .

${ }^{32}$ Od 1946 r. Naczelna Dyrekcja Bibliotek.

${ }^{33}$ W Wydziale pracowali m.in. Adam Łysakowski, Józef Janiczeki, Marian Falski.

${ }^{34}$ Cyt. za: Potyczki ze źródlami bibliologicznymi..., s. 17.

${ }^{35}$ J. Grycz, Problemy biblioteczne obecnej doby, „Przegląd Biblioteczny”, 1946, s. 46; K. Janiczek, Sprawy biblioteczne w ramach dzialalnosci Ministerstwa Oświaty, „Bibliotekarz", nr 1/2,1946, s. 1-13. Do spraw ogólnych odnosił się także K. Świerkowski w artykule: Zabezpieczanie ksiegozbiorów poniemieckicl i podworskich oraz sprawa ich zuzytkowania, w: Aktualne zagadnienia bibliotekarskie. Pierwsza powojenna konferencja okreggonrych wizytatorów bibliotek w dniach 21-27 października 1945 r: w Pabianicach, Warszawa 1946, s. 25-32.

${ }^{36} \mathrm{~Np}$. K. Tymecki, Biblioteki w Gdyni i na Wybrzeżu w latach 1939-1946, „Bibliotekarz", nr 6/7, 1946, s. 144-145.

${ }^{37}$ Obok wspomnianych artylułów J. Grycza, Problemy biblioteczne..., s. 22-23 i K Janiczka, Sprawy biblioteczne..., s. 1-7, także publikacje: M. Dembowska, Wodzinowska, Stan bibliotek polskich, „Przegląd Biblioteczny”, z. 1/2, 1947, s. 12-23; Taż: Biblioteki polskie po wojnie, „Wiedza i zycie”, nr 1/2, 1947, s. 151-156; A. Birkenmajer, Les bibliotheques polonaises entre 1938 et 1947, „Actes du Comite International des Bibliotheques 13 sess", vol. 12, 1947, s. 261-265.

${ }^{38}$ M.in.: A. Lewak, Polskie biblioteki naukowe zniszczone w $1939 / 44$ r., „Kwartalnik Historyczny", z. 3/4, 1939-1945, s. 687-699; S. Konopka, Polskie biblioteki lekarskie, Warszawa 1945; Pracownie naukowe szkól wyższych w Polsce 1945/1946. [Red. M. Falski]. Warszawa 1947.

${ }^{39}$ M.in.: S. Bodniak, Straty wojenne zborów reckopiśniennych bibliotecznych, w: Sprawozdania Poznańskiego Towarzystwa Przyjaciól Nauk 1945/1946, ur 1, s. 31/32; S. F. Michalski, Straty orientalistyki polskiej, w: Odrodzenie, nr 43, 1945, s. 7; J. Kostrzewski, Losy nauk prehistoryczuych w czasie wojny i po wojnie, w: Nauka Polska, t. 25, 1947, s. 132-154; W. Sierpiński, Matenatyka polska w czasie wojny i po woinie, w: Nauka Polska, t. 25, 1947, s. 93-94.

${ }^{40}$ M.in.: Sprawozdanie $z$ dzialalności Kuratorium Okregu Szkolnego Poznańskiego w zakresie bibliotekarstwa w czasie od korica kwietnia do 15 października 1945 roku, w: Aktualne zagadnienia bibliotekarskie. Pierwsza powojenna konferencja wizytatorów w dniach 24-27 października 1945 r. w Pabianicach, Warszawa 1946, s. 109-120;

$\mathrm{Cz}$. Pilichowski, Szkody materialne i moralne szkolnictwa wielkopolskiego od r. 19391945, „Polska Zachodnia”, nr 4, 1945, s. 4; K. M. Pospieszalski, Polska pod niemieckinn prawem 193.-1945 (Ziemie Zachodnie), Poznań 1946.

${ }^{41}$ M.in.: J. Baumgart, Biblioteki poznańskie 1939-1945, „Bibliotekarz”, nr 4, 1946 , s. 92-93; J. Kostrzewski, Biblioteka Muzeum Prehistorycznego [w Poznaniu], w: Ksiązka i Kultura, nr 5, 1947, s. 6-7. 
${ }^{42}$ S. Bodniak, Sprawozdanie z prac w Bibliotece Kórnickiej za okres od 22 stycznia 1945 r: do 30 czerwca 1945 r., "Pamiętnik Biblioteki Kórnickiej”, z. 3, 1939-1946, s. 315322; Tenze: Sprawozdanie kierownictwa Biblioteki Kórnickiej za okres administracyiny od 1 lipca 1945 roku do 30 czerwca 1946 roku, ibidem, s. 323-330; S. Bodniak, Zbiory naukowe w Kórniku za okupacii i obecnje, „Przegląd Zachodni”, n1 4, 1946, s. 385-390; Sprawozdanie Biblioteki Akademii Handlowej w Poznaniu za lata 1939-1946, „Rocznik Akademii Handlowej w Poznaniu" 1945-1945/46, s. 130-133.

${ }^{43}$ M.in.: K. Swierkowski, Warszawskie biblioteki naukowe, „Bibliotekarz" , nr 1, 1945, s. 10; W. Borowy, Białe kruki wśród ruin Warszawy, w: Radio i Świat, 1945, nr 10, s. 3; H. P., 317 tys. ksiazzek splonęlo w Bibliotece Publicznej w Warszawie, "Gazeta Ludowa”, nr 25, 1945, s. 4; H. Hleb-Koszańska, Biblioteka Instytutu Baltyckiego, „Bibliotekarz", n1 10, 1946, s. 214-215; B. Horodyski, Fragment katalogu dokumentów pergaminowych Biblioteki Ordynacji Zamojskiej, „Przegląd Historyczny”, 1946, s. 96-98; J. Krzyżanowski, Nauka w Warszawie, w: Odrodzenje, nr 20, 1945, s. 3; M. Łodyński, Biblioteki $w$ odbudowującym się żciu naukowym Warszawy, "Przegląd Historyczny", t. 36, s. 42-50; T. Mikulski, Popiół, Warszawa, nr 6, 1946, s. 4; Odnalezienie cennego księgozbioru Biblioteki Publicznej m. st. Warszawy w Pradze Czeskiej, „Zycie Warszawy”, nr 180, 1945, s. 3; Nauka polska ma prawo do odszkodowań, w: Kronika Odbudowy Warszawy, 1946, nr 11, s. 5-7; Warszawa oskarża. Przewodnik po wystawie urządzonej przez Biuro Odbudowy Stolicy wespół z Muzeum Narodowyn w Warszawie. Warszawa, maj-czerwiec 1945, Warszawa 1945; S. Wierczyński, Biblioteka Narodowa, „Tygodnik Warszawski", nr 42, 1945, s. 6; H. Bohosiewiczowa, Biblioteka Warszawskiego Towarzystwa Lekarskiego, „Przegląd Biblioteczny”, z. 1/2, 1947, s. 58-61; S. Konopka, Główna Biblioteka Lekarska w 1945 i 1946 roku, "Polski Tygodnik Lekarski ”, nr 2, 1947, s. 11, 14; nr 3, s. 19, T. Makowiecki, Warszawska Biblioteka Uniwersytecka 1939-1944, Frankfurt n. Menem 1947; L. Sawicki, Państwowe Muzeum Archeologiczne. (Okres międzywojenny, okupacji i lata 1945-1947). Sprawozdania P(aństwowego] M(uzeum] A/rcheologicznego/, Warszawa 1945-1947, s. 25-26, 30.

${ }^{44}$ Np. A. M. Friedberg, Archiwa $i$ biblioteli krakowskie, w: Kraków pod rządami wroga 1939-1945, Kraków 1945. Zol). też wykaz opracowań w P. Lechowski, Biblioteki Krakowa..., s. 131-138.

${ }^{45}$ M.in.: Straty wojenne bibliotek lubelskich, „Glos Ludu”, nr 26, 1945, s. 4; H. Wolańska, Centralna Biblioteka Pedagogiczna przy Kuratorium Okregu [Szkolnego] Lubelskiego, „Bibliotekarz”, nr 8/9, 1946, s. 185-186; Z. Ziemkiewicz, Miejska Biblioteka Publiczna [w Lublinie], „Bibliotekarz”, nr 8/9, 1946, s. 183-184.

${ }^{46}$ M.in.: J. Warężak, Rejestracja szkód wojennych w Eodzi, w: Dziennik Zarządu Miejskiego w Eodzi, 1945, nr 1, s. 13-28.

${ }^{47}$ M.in: J. Przybylowa, Biblioteki Torunia. Bibliotekarz 1946 nr 10 s. 208-210; Biblioteka Uniwersytecka i Ksiąznica Miejska inn. Kopernika w Toruniu, „Kwartalnik Historyczny", z. 3/4, 1939-1946, s. 751-752.

${ }^{48}$ M.in.: F. Kotula, $Z$ dziejów Rzeszowa 1939-1944. Losy rzeszowskich zabytków i pamiątek, Rzeszów 1947.

${ }^{49}$ M.in.: M. Kieffer, „Bibliotekarz”, nr 11/12, 1946, s. 244-246; Niepowetowane straty Plocka w dziedzinie Kultury i sztuki, „Robotnik Mazowiecki”, nr 4, 1945, s. 5.

${ }^{50}$ Np. Z. Rutkowska, Biblioteka Szkoły im. Vetterów, „Bibliotekarz”, nr 8/9, 1946 , s. $187-188$. 
${ }^{51}$ M.in.: J. Marcinkiewicz, Publiczna Biblioteka Powiatowa w Kielcach, „Bibliotekarz", nr 6/7, 1946, s. 149; S. Podhorska-Okolów, Bibliotelsa Miejska w Czestochowie, „Bibliotekarz”, nr 6/7, 1946, s. 150-151; J. Rogala, Biblioteka Powiatowa w Garwolinie, "Bibliotekarz”, nr 11/12, 1946, s. 246; J. Stępieniowa, Biblioteka Miejska w Pabianicach [calkowicie zniszczona przez Niemców], „Bibliotekarz”, nr 2/3, 1945, s. 15-16; S. Szczęsny, Biblioteka Powiatowa w Jedrzejowie, „Bibliotekarz”, nr 6/7, 1946, s. 152; A. Szulc, Biblioteka [w Lubartowie], „Bibliotekarz”, nr 8/9, 1946, s. 188-189; S. Waćkowska, Biblioteka Miejska /w Siedkach], „Bibliotekarz”, nr 8/9, 1946, s. 189-190; Z. Wilczewski, Dzieje Biblioteki Miejskiej w Białynstoku, w: Jednośc Narodowa, 1946, n1 47, s. 4; F. Szymiczek, Sląska Biblioteka Publiczna w Katowicach po wojnie, w: Zaranie Sląskie, Z. 1/2, 1947, s. $71-74$.

${ }^{52}$ M.in.: Pięć wagonów dziel sztuki ze zbiorów polskich odnaleziono na terenie Nienniec, w: Jedność Narodowa, 1947, nr 33, s. 2; Rewindykowanie cennych rękopisów i książek, „Tygodnik Warszawski”, 1947, nr 28, s. 8.

${ }^{53}$ A. Kawecka-Gryczowa, Ochrona zbiorów w Bibliotece Narodowej, w: Walka..., t. 1, s. 241.

${ }^{54}$ Warszawa 1947.

${ }^{55}$ B. Bieńkowska, Potyczki ze źródlami bibliologicznynni, s. 17.

${ }^{56}$ E. Chwalewik, Wojenne straty polskich zbiorów exlibrisów, Wroclaw 1949.

${ }^{5}$ A. Chybiński, Rejestracja i zabezpieczenie zabytków muzyki polskiej, w: Kwartalnik Muzyczny, 1949, z. 25, s. $183-190$ (na s. 190-192 koreferat A. Simon).

${ }^{58}$ L. Zembrzuski, Biblioteki lekarskie w Polsce. Szkic historyczny, Warszawa 1948.

${ }^{59}$ M.in.: Katalog wystawy rękopisów i druków wywiezionych przez hitlerowców do Niemiec, uratowanych przez Armię Czerwoną i przekazanych Polsce przez Rząd Radziecki. Warszawa 1948 i artykul na ten temat P. Koczorowskiego: Wystawa rekopisów idruków, wywiezionych przez hitlerowców do Niemiec, uratowanych przez Armie Czerwoną i przekazanych Polsce przez Rząd Radziecki, „Bibliotekarz”, 1948, n 10/11, s. 160 162; Odzyskane zbiory, „Biuletyn Polskiego Towarzystwa Przyjaciół Książki”, nr 7 , 1948, k. 6-7.

${ }^{60}$ M.in. Straty kulturalne Warszawy, t. 1. Praca zbiorowa pod red. W. Tomkiewicza. Warszawa 1948; A. Lewak, Biblioteki naukowe, w: Straty kulturalne Warszawy, t. 1. Warszawa 1948, s. 111-126; T. Manteuffel, Uniwersytet Warszawski w latach wojny i okupacji. Kronika 1939/40-1944/45, Warszawa 1948; Tenze: Uniwersytet Warszawski w latach wojny $i$ okupacji, w: Straty kulturalne Warszawy, t. 1, Warszawa 1948; Z. Rothertowa, Biblioteka [Muzeum Narodowegol, w: Straty kulturalne Warszawy, t. 1, Warszawa 1948, s. 245-247; S. M. Sawicka, Gabinet Rycin Biblioteki Uniwersyteckiej w Warszawie w latach 1939-1949, „Biuletyn Historii Sztuki i Kultury”, nr 3/4, 1949, s. 392-397; Warszawa w liczbach 1947, Warszawa 1948; H. Więckowska, Dodatek do katalogu rękopisów batignolskich, „Przegląd Biblioteczny”, z. 1/2; 1949, s. 46-64; J. Zathey, O kilku przepadlych zabytkach relsopiśmiennych Biblioteki Narodowej w Warszawie, w: Studia $z$ dziejów kultury polskiej, Warszawa 1949, s. 73-95; B. Horodyski, Spuścizna działu rekkopiśmiennego Biblioteki Załuskich, „Przegląd Biblioteczny”, z. 1/2, 1948, s. 40-63.

${ }^{61}$ M.in. H. Szoldrska, Walka z kulturą polską. Uniwersytet Poznański podczas okurpacji, Poznań 1948. 